\section{AGRARIAN DISTRESS AND CROP INSURANCE IN ODISHA: SOME EMPIRICAL FINDINGS FROM KALAHANDI DISTRICT OF ODISHA}

Sasmita Patnaik

MamataSwain **

\begin{abstract}
In India, risks involved in agricultural production are inherently very high, which have increased appreciably due to climate change and globalisation. Both the government and the farmers take many ex-ante and ex-post measures to reduce risk and impart greater resilience to agriculture. However, in spite of the preventive measures in place, when there is crop failure, insurance is considered the most effective mechanism to compensate the farmers for their losses. Crop insurance is an ex-ante risk adaptive measure that transfers the production risk from the insured to the insurer. Realising the need of crop insurance for management of agricultural risk, Government of Odisha launched National Agricultural Insurance Scheme (NAIS) from the rabi season of 1999-2000 in all the thirty districts. NAIS is an area-based yield insurance scheme, providing coverage for yield losses due to natural calamities, pest attack and plant diseases and covers all food crops and major crops. This paper seeks to analyse the performance of NAIS in Kalahandi district of Odisha by using data from both secondary and primary sources. The principal objectives of the study are to identify the reasons for non-adoption of crop insurance by majority of farmers and explore the determinants of participation in the scheme. The study reveals that the performance of NAIS is not satisfactory due to its low coverage and undue delay in indemnity payment.
\end{abstract}

\footnotetext{
*Lecturer in Economics, Department of Rural Development, Ravenshaw University, E-mail: sasmita.mitu@yahoo.co.in

**ICSSR Senior Fellow, Professor of Economics, Ravenshaw University, Cuttack, Odisha-753003, E-mail: mama_swain@hotmail.com

The paper is based on the PhD thesis (2016) of the first author under the supervision of the second author undertaken at the Department of Economics, Ravenshaw University, Cuttack. The authors wish to thank South Asian Network for Development and Environmental Economics (SANDEE), Kathmandu, Nepal for the technical and financial support provided during the research work.
}

Journal of Rural Development, Vol. 36, No. 3, July-September : 2017 


\section{Introduction}

The new economic policy of globalisation, liberalisation and privatisation pursued by India since 1991 to accelerate the pace of development has created some challenges to the agriculture sector. During the post-reform period there has been a steady deceleration in the growth rate of agricultural output as compared with the decade before reforms. Public investment in agriculture has declined due to financial constraint. This has caused deterioration of rural infrastructure, stagnation in agricultural research and development and neglect of extension services. Withdrawal of input subsidies has increased cost of cultivation making agriculture unremunerative.

Owing to the exposure of domestic agriculture to international competition, crop prices have become more volatile and vulnerable to world commodity prices. On the top of it climate change has appeared as a major threat to Indian agriculture due to increase in occurrence of climate-induced natural disasters such as drought, flood and cyclone. Farmers are in great distress and are losing interest in agriculture owing to increase in cost of cultivation on the one hand and on the other hand, there is lot of uncertainty in agricultural production. The farmers do not have adequate access to credit and insurance to tide over financial hardships arising out of crop failures due to weather aberrations. In
India, large-scale farmer suicides during the last few years in States like Maharashtra, Karnataka, Andhra Pradesh and Odisha attest to the failure of public action in handling the problem of agricultural risk in the changed context of globalisation and climate change (Swain and Patnaik, 2016).

Odisha, in Eastern India, is an agriculture dependent poor State with high vulnerability to climate change. The State's economy is extremely vulnerable to natural disasters like drought, flood and cyclone because of its tropical climate, monsoon-based rain, a long coast line, high dependence on agriculture, mass poverty and low irrigation coverage (Swain, 2014). The agriculture sector is, thus, highly vulnerable to climate change characterised by extreme rainfall variability, recurrent but unpredictable droughts, high temperatures and low soil fertility.

\section{Agrarian Distress in Odisha}

The State has witnessed increasing farmer suicides since 1999. Crop loss, drought, debt-burden and volatility in prices have been cited as some of the reasons for the worrying trends. Lack of proper irrigation facilities in drought-prone areas is one of the prominent grievances among Odisha farmers. While farmers largely depend on monsoon during the kharif season, for the rabi crop a majority of the farmers keep their land idle due to water scarcity. Also, the minor and lift irrigation 
projects under different administrative controls are dysfunctional for different reasons. Droughts in the beginning of the season adversely affect the sown area leaving large portions of agricultural lands as fallow (Ahmed et al., 1998). Mid-season droughts result in poor crop growth and reduction in crop yields.

Increasing cost of fertilisers, agroappliances, seeds and high risk of crop loss due to myriad reasons, including natural calamities and absence of insurance, have been pushing small farmers and sharecroppers into abyss. Many of these farmers choose to migrate or end up dying due to starvation.

The constraints and barriers faced in the agriculture supply chains are non-availability of adequate critical infrastructure facilities like cold chain, packing and grading centres; lack of adequate quality control and testing infrastructure; lack of suitable varieties of farm produce for processing; seasonality of raw materials; high inventory carrying cost and packaging costs. Similarly, another important issue of the farmers is poor extension services in the State for which farmers are not aware of new and improved package of practices for growing crops.

On the credit front, the functioning of the rural cooperative credit institutions has deteriorated leading to growing dependence on non-institutional sources of credit at very high rates of interest. Except for a few crops, the procurement mechanism does not serve the purpose of ensuring minimum prices to agricultural producers. Moreover, the profit margin in agricultural produce is comparatively low as there are no adequate marketing facilities in the State.

Long-term factors like steeper decline in per capita land availability and shrinking of farm size are also responsible for the agrarian crisis. The agrarian crisis that has ravaged Odisha's countryside during the post-reform era has grown on a three-pronged set of symptoms: rising input costs, dwindling produce price realisation and the inability of farmers to abandon cultivation without alternative livelihood sources. The agricultural crisis is affecting a majority of the farmers in the State. The farmers who produce food materials are in deep distress. The marginalised people like the scheduled castes and scheduled tribes, who depend on agriculture, are getting unemployed and struggling for their livelihood. The ordinary people, especially the poor, have lost their food security. The crisis in agriculture is a crisis of the State as a whole and needs urgent attention.

\section{Insurance for Risk Management}

If markets exist to permit people to insure against shocks ex-ante, or to borrow ex-post, the adverse effects of risk could be attenuated. The existence of risk need not then contribute to plunge into the poverty traps. Unfortunately, credit and insurance 
instruments are routinely undersupplied in most low-income areas, and especially to the poorest people. Financial market failures thereby contribute both directly and indirectly to the persistence of chronic poverty (Carter and Barrett, 2006). Crop insurance policies are generally available only in countries where governments take on much of the catastrophic risk exposure faced by insurers (Binswanger and Rosenzweig, 1986; Miranda and Glauber, 1997). The need for insurance becomes but natural to transfer the various risks like production risk and price risk, involved in agriculture.

Realising the need for crop insurance for management of agricultural risk, the Government of India and the State of Odisha introduced different crop insurance schemes from time to time (AICl, 2007). The National Agricultural Insurance Scheme (NAIS) has been implemented in Odisha since 1999 rabi season, following the Government of India guidelines. In Odisha, NAIS is under implementation in all the thirty districts.

NAIS covered all food crops (cereals, millets and pulses), cotton, sugarcane and potato in the first year and other annual commercial/ horticultural crops in a period of three years. All loanee farmers were compulsorily covered under the scheme. The non-loanee farmers growing insurable crops could also opt for the scheme. The scheme provided comprehensive risk insurance against yield losses due to natural fire, lightening, storm, hailstorm, cyclone, typhoon, tempest, hurricane, tornado, flood, inundation and landslide, drought, dry spell, pests, diseases, etc.

The sum insured extends to the value of the threshold/guaranteed yield of the crop, with an option to cover up to 150 per cent of the average yield of the crop on payment of an extra premium. In Odisha, the kharif season starts from May and ends in October and the rabi season starts from November and ends in April. In the kharif season, the premium rate for bajra and oilseeds is 3.5 per cent of the sum insured and 2.0 percent for other food crops. In the rabi season, the premium rate is 1.5 per cent for wheat and 2.0 percent for other food crops and oilseeds. Furthermore, a 50 percent subsidy in the premium is allowed to small and marginal farmers that will be shared equally by the Government of India and the State Government with the subsidy to be phased out within a period of 5 years. In Odisha, however, this subsidy has been reduced to just 10 percent of the sum insured. NAIS operates on the basis of area approach. If the actual average yield per hectare of the insured crop for the defined area (on the basis of requisite number of Crop Cutting Experiments) in the insured season, falls short of specified threshold yield, all the insured farmers growing that crop in the defined area are deemed to have suffered shortfall in their yield and the scheme provides coverage against such contingency. Indemnity claims are worked out as per the following formula:

Shortfall in Yield X Sum Insured for the farmer Threshold Yield 
(Shortfall $=$ Threshold Yield - Actual Yield for the Defined Area).

Threshold yield is the moving average based on past three years average yield in case of rice and wheat and five years average yield in case of other crops.

This paper attempts to critically examine the efficacy of NAIS under implementation in Kalahandi district in Western Odisha as a risk management strategy during agrarian distress. In the changed environment of increased agricultural risk due to climate change, globalisation and commercialisation of agriculture, there is a need to introduce innovative insurance products to cater to the needs of the farmers (Swain, 2008 and 2014).

\section{Methodology}

In order to understand the effectiveness of NAIS as a risk management tool at the ground level, a field survey was conducted in Kalahandi district in western Odisha. The districts of southern and western Odisha are regarded as the most backward regions by the Planning Commission and some of these districts have been re-designated as KBK (Kalahandi-Balangir-Koraput) region. Kalahandi district of Odisha, in particular, is part of the KBK region of Odisha and is known for its high incidence of mass and chronic poverty and high tribal population. Persistent crop failure, lack of access to the basic services and entitlements, starvation, malnutrition and migration are the leading manifestations in Kalahandi. Severe droughts and floods also often visit this region in quick succession. Therefore, backwardness of this region is multifaceted: (i) backwardness due to severe natural calamities, (ii) tribal backwardness, (iii) hill area backwardness and (iv) apathy of State and Central governments towards this region.

In this study, a multi-stage stratified random sampling technique was followed. In the first stage, for assessing the performance of NAIS, Kalahandi district was chosen as the study area because of its high vulnerability to drought as compared to other districts in Odisha. In the second stage, five blocks were selected from Kalahandi district. In the third stage, two villages from each of the identified block were selected according to highest coverage by NAIS. Finally, ten households who were NAIS users and also loanees were selected from each village randomly. Also, five non-loanee NAIS users and five non-users of NAIS were selected randomly from each village. Thus, a total of 200 households were included. Primary data were collected from these households by direct questionnaire method with the help of a structured questionnaire.

Data were collected from both primary and secondary sources. Data on NAIS and statistics related to performance of the insurance scheme were obtained from the implementing agency, i.e., Regional Office of Agriculture Insurance Company of India Limited (AICL), Bhubaneswar. Time series data were collected from the year of inception of the scheme in the State. Thus, secondary data 
for NAIS for the period 1999 to 2011 were collected to examine the trend in the scheme performance.

\section{Coverage of Crop Insurance Scheme in Odisha}

To evaluate the performance of NAIS in Odisha, the trends in the coverage of the scheme in both kharif and rabi seasonshave been shown in Table 1 and Figure 1. As shown in Table 1, during kharif season, the number of farmers covered has increased substantially from 6.8 lakh in 2000 to 14.4 lakh in 2011. The area covered has also increased from 7.5 lakh hectares in 2000 to 15.0 lakh hectares in 2011.

During rabi season, the number of farmers covered has declined from 1.2 lakh in 2000 to 0.7 lakh in 2011. Likewise, the coverage area during rabi seasons has declined from nearly one lakh hectares in 2000 to 0.8 lakh hectares in 2011(Table 1, Figure 1). Thus, the trend in the coverage of the scheme during rabi seasons reveals that the coverage of the scheme with respect to number of farmers and area covered has declined over the period 2000-2011.This is because rabi crops are usually grown in irrigated areas, where requirement for insurance is low.

Now coming to total area under NAIS which includes both kharif and rabi crops, it has increased substantially from 8.6 lakh hectares in 2000 to 15.8 lakh hectares in 2011. In the same period, the area covered during kharif as a percentage of total area also increased enormously from 87.4 to 94.8 per cent. But, the area covered during rabi as a percentage of total area covered declined from 12.6 per cent to only 5.2 per cent.

Table 1: Coverage of National Agricultural Insurance Scheme (NAIS) in Odisha (Kharif and Rabi 2000-2011)

\begin{tabular}{|c|c|c|c|c|c|c|c|c|}
\hline & \multicolumn{3}{|c|}{ Farmers Covered under NAIS } & \multicolumn{3}{|c|}{ Area Covered under NAIS (ha.) } & \multirow{2}{*}{$\begin{array}{c}\text { Gross } \\
\text { Cropped } \\
\text { Area (GCA) } \\
\text { (ha.) }\end{array}$} & \multirow{2}{*}{$\begin{array}{c}\% \text { of GCA } \\
\text { under } \\
\text { NAIS }\end{array}$} \\
\hline & Kharif & Rabi & $\begin{array}{c}\text { Kharif } \\
\text { and Rabi }\end{array}$ & Kharif & Rabi & $\begin{array}{c}\text { Kharif } \\
\text { and Rabi }\end{array}$ & & \\
\hline 2000 & $\begin{array}{c}681010 \\
(84.6)\end{array}$ & $\begin{array}{c}123964 \\
(15.4)\end{array}$ & $\begin{array}{c}804974 \\
(100.0)\end{array}$ & $\begin{array}{c}751595 \\
(87.4)\end{array}$ & $\begin{array}{c}108810 \\
(12.6)\end{array}$ & $\begin{array}{r}860405 \\
(100.0)\end{array}$ & 8526000 & 10.1 \\
\hline 2001 & $\begin{array}{c}627568 \\
(74.7)\end{array}$ & $\begin{array}{c}212162 \\
(25.3)\end{array}$ & $\begin{array}{c}839730 \\
(100.0)\end{array}$ & $\begin{array}{c}625098 \\
(78.1)\end{array}$ & $\begin{array}{c}174899 \\
(21.90\end{array}$ & $\begin{array}{l}799997 \\
(100.0)\end{array}$ & 7877960 & 10.2 \\
\hline 2002 & $\begin{array}{c}1204849 \\
(89.4)\end{array}$ & $\begin{array}{c}142871 \\
(10.6)\end{array}$ & $\begin{array}{c}1347720 \\
(100.0)\end{array}$ & $\begin{array}{c}1377756 \\
(91.8)\end{array}$ & $\begin{array}{c}123475 \\
(8.2)\end{array}$ & $\begin{array}{c}1501231 \\
(100.0)\end{array}$ & 8798610 & 17.1 \\
\hline 2003 & $\begin{array}{c}638303 \\
(75.9)\end{array}$ & $\begin{array}{c}202699 \\
(24.1)\end{array}$ & $\begin{array}{r}841002 \\
(100.0)\end{array}$ & $\begin{array}{c}633977 \\
(78.1)\end{array}$ & $\begin{array}{c}178181 \\
(21.9)\end{array}$ & $\begin{array}{c}812158 \\
(100.0)\end{array}$ & 7852560 & 10.3 \\
\hline 2004 & $\begin{array}{c}872551 \\
(80.5)\end{array}$ & $\begin{array}{c}210853 \\
(19.5)\end{array}$ & $\begin{array}{c}1083404 \\
(100.0)\end{array}$ & $\begin{array}{c}943212 \\
(82.6)\end{array}$ & $\begin{array}{c}198026 \\
(17.4)\end{array}$ & $\begin{array}{c}1141238 \\
(100.0)\end{array}$ & 8638000 & 13.2 \\
\hline 2005 & $\begin{array}{c}900022 \\
(79.6) \\
\end{array}$ & $\begin{array}{c}230039 \\
(20.4) \\
\end{array}$ & $\begin{array}{c}1130061 \\
(100.0) \\
\end{array}$ & $\begin{array}{c}922854 \\
(81.0) \\
\end{array}$ & $\begin{array}{c}216780 \\
(19.0)\end{array}$ & $\begin{array}{c}1139634 \\
(100.0) \\
\end{array}$ & 8718000 & 13.1 \\
\hline
\end{tabular}

Journal of Rural Development, Vol. 36, No. 3, July-September : 2017 
Table 1 (Contd.....)

\begin{tabular}{|ccccccccc|}
\hline 1 & 2 & 3 & 4 & 5 & 6 & 7 & 8 & 9 \\
\hline 2006 & 880330 & 199886 & 1080216 & 890122 & 199725 & 1089847 & 8928000 & 12.2 \\
& $(81.5)$ & $(18.5)$ & $(100.0)$ & $(81.7)$ & $(18.3)$ & $(100.0)$ & & \\
2007 & 840727 & 132418 & 973145 & 905934 & 138534 & 1044468 & 8960000 & 11.7 \\
& $(86.4)$ & $(13.6)$ & $(100.0)$ & $(86.7)$ & $(13.3)$ & $(100.0)$ & & \\
2008 & 611477 & 161720 & 773197 & 590932 & 144564 & 735496 & 9014000 & 8.2 \\
& $(79.1)$ & $(20.9)$ & $(100.0)$ & $(80.3)$ & $(19.70$ & $(100.0)$ & & \\
2009 & 1068687 & 134672 & 1203359 & 981287 & 131502 & 1112789 & 9071000 & 12.3 \\
& $(88.8)$ & $(11.2)$ & $(100.0)$ & $(88.2)$ & $(11.8))$ & $(100.0)$ & & \\
2010 & 1107710 & 34676 & 1142386 & 1031185 & 31705 & 1062890 & 9075000 & 11.7 \\
& $(97.0)$ & $(3.0)$ & $(100.0)$ & $(97.0)$ & $(3.0)$ & $(100.0)$ & & \\
2011 & 1443203 & 69150 & 1512353 & 1501147 & 82333 & 1583480 & 8801080 & 18.0 \\
& $(95.4)$ & $(4.6)$ & $(100.0)$ & $(94.8)$ & $(5.2)$ & $(100.0)$ & & \\
$2000-2011$ & 10877355 & 1855110 & 12732465 & 11156032 & 1728534 & 12884566 & 104260210 & 12.4 \\
& $(85.4)$ & $(14.6)$ & $(100.0)$ & $(86.6)$ & $(13.4)$ & $(100.0)$ & & \\
\hline
\end{tabular}

Sources: (i) Agriculture Insurance Company of India Limited (AICL), Regional Office, Bhubaneswar, Odisha.

(ii) Orissa Agricultural Statistics, Various Issues, Directorate of Agriculture and Production, Odisha, Bhubaneswar.

Figure 1: Kharif and Rabi Area under NAIS in Odisha (2000-2011)

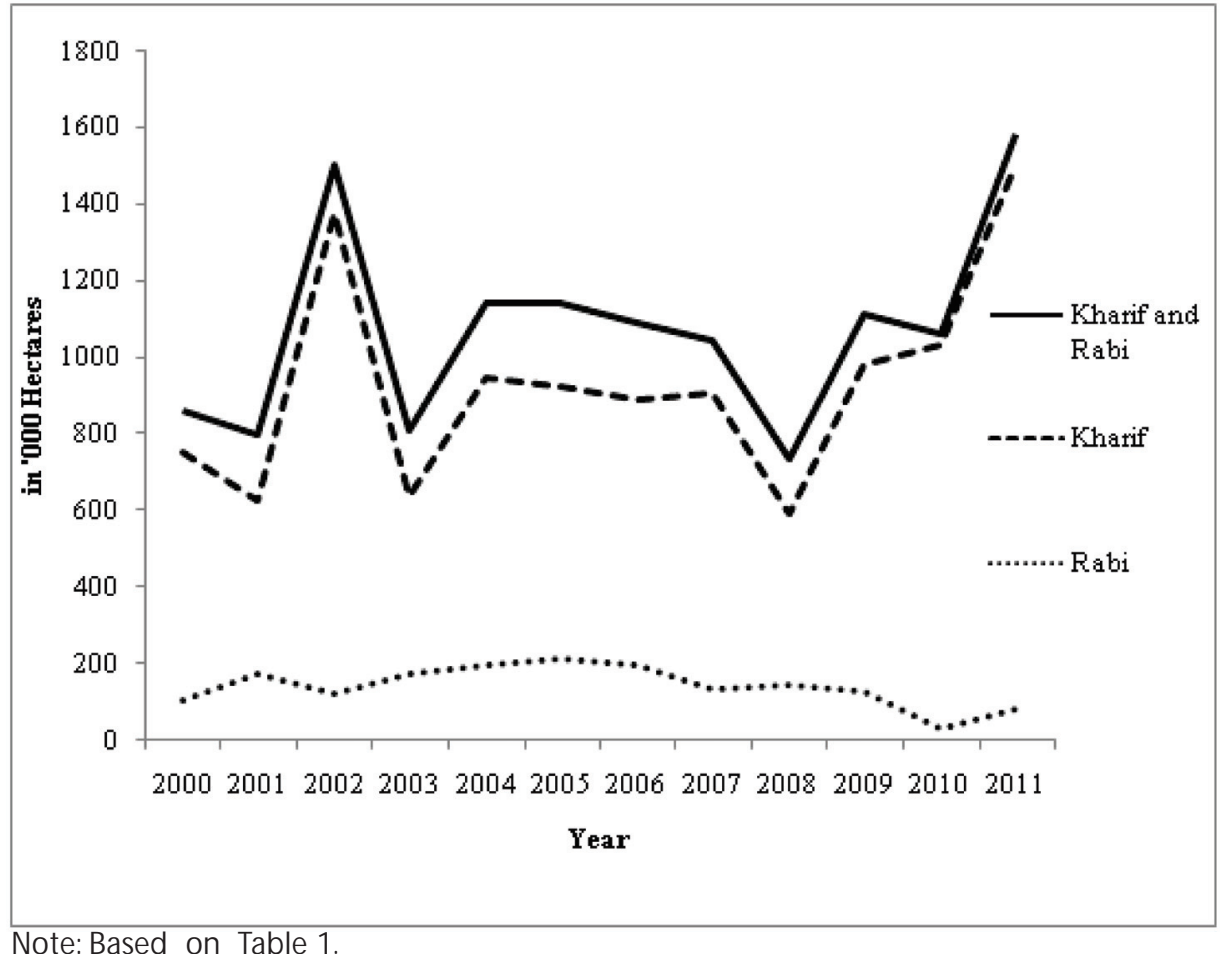

Journal of Rural Development, Vol. 36, No. 3, July-September : 2017 
The percentage of Gross Cropped Area under NAIS has also increased from 10.1 per cent in 2000 to 18.0 per cent in 2011. The percentage of Gross Cropped Area under NAIS is computed to be only 12 per cent during the period 2000-2011. Thus, 88 per cent of GCA has not yet been covered under insurance. Of course, during drought years of 2002 and 2011, the coverage of NAIS was higher, i.e., 17 and 18 per cent, respectively (Table 1).

\section{Performance of NAIS in Kalahandi District}

Kalahandi district is predominantly agrarian in nature. Cultivation is the major source of income for more than 90 percent of the population living in the rural areas. In the district, the percentage of gross irrigated area to gross cropped area is only 26 per cent. Agriculture in the district is mostly rainfed. NAIS has been implemented in all the blocks of Kalahandi since 1999.

For loanee farmers taking crop loans from institutional sources such as commercial banks, cooperatives and regional rural banks, NAIS is compulsory; but for non-loanee farmers who have not availed of any crop loans from institutional sources during the crop season, it is voluntary. Therefore, we have undertaken a break-up analysis of area and farmers covered according to loanee and non-loanee category.
The non-loanee farmers have been emphasised upon to examine the farmers' adoption rate of NAIS voluntarily. The analysis has been made for kharif and rabi seasons separately.

During kharif 2011, the percentage of area covered under NAIS in the study area of Kalahandi was as high as 34.5 per cent compared to all Odisha average of 25.9 per cent (Table 2). The adoption rate of NAIS, as reflected by the percentage of non-loanee farmers covered under NAIS, is also very high at 60.4 per cent in comparison to all Odisha average of 12.3 per cent. Likewise, percentage of area covered by non-loanee farmers under NAIS is 54.6 per cent while that of the State is 18.4 per cent.

During the kharif season, the percentage of farmers benefited under NAIS in Kalahandi is observed to be 71.7 per cent in comparison to the State average of 39.6 per cent (Table 3). Also as can be observed from Table 4, during the rabi season, the percentage of farmers benefited under NAIS is observed to be 15.4 per cent while the State average is merely 1.8 per cent. The claim to premium ratio in Kalahandi during Kharif 2011-12 is 12.0, whereas it is only 8.4 in Odisha (Table 3). This shows that farmers in drought-prone area of Kalahandi are more benefited by NAIS. 
Table 2: District and Region-wise Coverage of NAIS in Odisha (Kharif 2011-12)

\begin{tabular}{|c|c|c|c|c|}
\hline Region/District & $\begin{array}{l}\% \text { of GCA } \\
\text { Irrigated }\end{array}$ & $\begin{array}{c}\% \text { of Kharif Area } \\
\text { under NAIS }\end{array}$ & $\begin{array}{c}\% \text { of Non-loanee } \\
\text { Farmers }\end{array}$ & $\begin{array}{c}\% \text { of Area of Non- } \\
\text { loanee Farmers }\end{array}$ \\
\hline \multicolumn{5}{|c|}{ Northern Plateau } \\
\hline Mayurbhanj & 34.2 & 9.8 & 0.1 & 0.1 \\
\hline Keonjhar & 27.0 & 15.3 & 1.0 & 1.5 \\
\hline Sundargarh & 27.5 & 19.4 & 14.3 & 26.3 \\
\hline Jharsuguda & 24.6 & 39.1 & 5.3 & 11.5 \\
\hline Deogarh & 31.7 & 15.0 & 4.6 & 10.8 \\
\hline Total & 29.7 & 15.9 & 6.2 & 11.5 \\
\hline \multicolumn{5}{|c|}{ Central Table Land } \\
\hline Bolangir & 18.5 & 34.9 & 67.2 & 70.1 \\
\hline Sambalpur & 38.8 & 42.8 & 11.4 & 18.4 \\
\hline Bargarh & 54.3 & 20.1 & 14.8 & 23.8 \\
\hline Dhenkanal & 37.7 & 26.5 & 0.3 & 0.4 \\
\hline Sonepur & 51.5 & 42.3 & 31.7 & 36.1 \\
\hline Angul & 21.2 & 38.5 & 0.4 & 0.7 \\
\hline Boudh & 28.1 & 46.6 & 4.1 & 7.5 \\
\hline Nawapara & 20.5 & 17.0 & 100.0 & 100.0 \\
\hline Total & 33.9 & 31.5 & 26.8 & 33.3 \\
\hline \multicolumn{5}{|l|}{ Eastern Ghat } \\
\hline Koraput & 34.5 & 7.5 & 2.2 & 2.0 \\
\hline Kalahandi & 26.2 & 34.5 & 60.4 & 54.6 \\
\hline Kandhamal & 16.9 & 12.3 & - & - \\
\hline Rayagada & 19.0 & 15.8 & 0.2 & 0.1 \\
\hline Gajapati & 28.2 & 14.2 & - & - \\
\hline Nowrangpur & 20.5 & 23.6 & 8.0 & 25.3 \\
\hline Malkanagiri & 26.9 & 8.4 & 0.1 & 0.2 \\
\hline Total & 25.5 & 19.1 & 29.4 & 30.8 \\
\hline \multicolumn{5}{|l|}{ Coastal Plain } \\
\hline Balasore & 62.3 & 36.2 & 0.3 & 0.5 \\
\hline Cuttack & 55.2 & 21.8 & 0.1 & 0.1 \\
\hline Puri & 58.8 & 37.3 & - & - \\
\hline Ganjam & 28.8 & 27.4 & 0.3 & 0.5 \\
\hline Bhadrak & 51.4 & 31.1 & - & - \\
\hline Jajpur & 35.6 & 18.0 & - & - \\
\hline Jagatsinghpur & 63.3 & 32.2 & - & - \\
\hline Kendrapara & 50.3 & 28.2 & - & - \\
\hline Khurda & 37.3 & 97.1 & 0.4 & 0.2 \\
\hline Nayagarh & 27.6 & 20.2 & 3.3 & 6.4 \\
\hline Total & 45.3 & 32.6 & 0.3 & 0.5 \\
\hline All Odisha & 35.1 & 25.9 & 12.3 & 18.4 \\
\hline
\end{tabular}

Source: Computed from data collected from AIC, Regional Office, Bhubaneswar, Odisha.

Journal of Rural Development, Vol. 36, No. 3, July-September : 2017 
Table 3: District and Region-wise Performance Indicators of NAIS in Odisha

(Kharif 2011-12)

\begin{tabular}{|c|c|c|c|c|c|c|c|}
\hline \multirow[t]{2}{*}{ Region / District } & \multirow{2}{*}{$\begin{array}{c}\% \text { of } \\
\text { GCA } \\
\text { Irrigated }\end{array}$} & \multicolumn{3}{|c|}{$\%$ of Farmers Benefited } & \multicolumn{3}{|c|}{ Claim / Premium } \\
\hline & & Loanee & $\begin{array}{l}\text { Non- } \\
\text { loanee }\end{array}$ & Total & Loanee & $\begin{array}{l}\text { Non- } \\
\text { loanee }\end{array}$ & Total \\
\hline \multicolumn{8}{|c|}{ Northern Plateau } \\
\hline Mayurbhanj & 34.2 & 3.7 & - & 3.7 & 0.1 & - & 0.1 \\
\hline Keonjhar & 27.0 & 14.7 & 5.2 & 14.6 & 2.9 & 1.6 & 2.9 \\
\hline Sundargarh & 27.5 & 3.1 & 1.6 & 2.9 & 0.3 & 0.3 & 0.3 \\
\hline Jharsuguda & 24.6 & 24.3 & 48.8 & 25.6 & 5.3 & 6.4 & 5.4 \\
\hline Deogarh & 31.7 & - & - & - & - & - & - \\
\hline Total & 29.7 & 9.2 & 6.5 & 9.0 & 1.7 & 1.7 & 1.7 \\
\hline \multicolumn{8}{|c|}{ Central Table Land } \\
\hline Bolangir & 18.5 & 97.2 & 99.7 & 98.9 & 27.9 & 25.9 & 26.5 \\
\hline Sambalpur & 38.8 & 7.1 & 9.5 & 7.4 & 0.7 & 1.1 & 0.8 \\
\hline Bargarh & 54.3 & 18.3 & 65.4 & 25.3 & 1.3 & 6.0 & 2.3 \\
\hline Dhenkanal & 37.7 & 7.3 & 3.1 & 7.3 & 0.7 & 0.5 & 0.7 \\
\hline Sonepur & 51.5 & 53.1 & 86.7 & 63.7 & 12.5 & 18.7 & 15.2 \\
\hline Angul & 21.2 & 34.1 & 44.6 & 34.1 & 4.5 & 5.6 & 4.5 \\
\hline Boudh & 28.1 & 49.5 & 56.5 & 49.8 & 8.0 & 7.6 & 8.0 \\
\hline Nawapara & 20.5 & 0.0 & 79.6 & 79.6 & 0.0 & 15.2 & 15.2 \\
\hline Total & 33.9 & 33.9 & 85.4 & 47.7 & 5.9 & 17.6 & 10.0 \\
\hline \multicolumn{8}{|l|}{ Eastern Ghat } \\
\hline Koraput & 34.5 & 16.8 & 44.3 & 17.4 & 0.9 & 6.9 & 1.0 \\
\hline Kalahandi & 26.2 & 60.6 & 79.0 & 71.7 & 9.8 & 13.6 & 12.0 \\
\hline Kandhamal & 16.9 & 21.8 & - & 21.8 & 1.4 & - & 1.4 \\
\hline Rayagada & 19.0 & 42.0 & 76.7 & 42.0 & 3.3 & 8.9 & 3.3 \\
\hline Gajapati & 28.2 & 22.6 & - & 22.6 & 1.8 & - & 1.8 \\
\hline Nowrangpur & 20.5 & 60.0 & 85.0 & 62.0 & 8.5 & 17.7 & 9.3 \\
\hline Malkanagiri & 26.9 & 93.3 & 100.0 & 93.3 & 18.0 & 20.3 & 18.0 \\
\hline Total & 25.5 & 48.6 & 79.1 & 57.6 & 6.8 & 13.7 & 9.1 \\
\hline \multicolumn{8}{|l|}{ Coastal Plain } \\
\hline Balasore & 62.3 & 11.1 & - & 11.0 & 2.0 & - & 2.0 \\
\hline Cuttack & 55.2 & 38.8 & 56.1 & 38.8 & 15.6 & 21.9 & 15.6 \\
\hline Puri & 58.8 & 29.7 & 100.0 & 29.7 & 7.7 & 30.6 & 7.7 \\
\hline Ganjam & 28.8 & 88.9 & 100.0 & 88.9 & 19.5 & 32.5 & 19.5 \\
\hline Bhadrak & 51.4 & 39.1 & - & 39.1 & 9.4 & . & 9.4 \\
\hline Jajpur & 35.6 & 62.8 & 100.0 & 62.8 & 1.9 & 39.0 & 1.9 \\
\hline Jagatsinghpur & 63.3 & 6.4 & - & 6.4 & 1.5 & - & 1.5 \\
\hline Kendrapara & 50.3 & 27.8 & - & 27.8 & 9.5 & - & 9.5 \\
\hline Khurda & 37.3 & 29.2 & 83.9 & 29.4 & 6.2 & 20.7 & 6.3 \\
\hline Nayagarh & 27.6 & 53.7 & 55.7 & 53.8 & 9.6 & 11.2 & 9.6 \\
\hline Total & 45.3 & 38.8 & 54.9 & 38.8 & 8.8 & 14.6 & 8.8 \\
\hline All Odisha & 35.1 & 34.3 & 77.6 & 39.6 & 6.8 & 15.9 & 8.4 \\
\hline
\end{tabular}

Source: Computed from data collected from AIC, Regional Office, Bhubaneswar, Odisha.

Journal of Rural Development, Vol. 36, No. 3, July-September : 2017 


\section{Survey Findings}

Socio-economic Profile of Insurance Users and

Non-users: The functional efficiency of any agricultural insurance scheme depends on its adoption rate. The adoption of insurance in turn depends on various socio-economic characteristics of farmers which include their social composition, educational attainment, occupation and sources of income, landholding pattern, asset position and net farm income. Therefore, the socio-economic profile of insurance users and non-users in the study area has been examined. A comparison of socioeconomic characteristics of users and non-users of crop insurance reveals that the majority of the loanee and non-loanee NAIS users belong to general castes and SEBCs (86 per cent). On the contrary, 56 per cent of non-users belong to general castes and SEBC. Thus, the percentage of SC and ST is more among non-users (44 per cent) than among insurance users (14 per cent)(Table 4). Moreover, there are no farmers of general category among the non-users. This shows that the higher caste households have opted for insurance. Median family size is 6 in case of loanee farmers, which is considered high. Average family size of non-loanee users and non-users of NAIS is 4 . The proportion of farmers having education of primary level (class 5 ) and above is 87 per cent in case of loanees, 92 per cent in case of non-loanees and 82 per cent in case of non-users. Thus, farmers with higher literacy rate have gone for insurance. $A$ majority of non-users are marginal and small farmers (76 per cent) in comparison to loanees (36 per cent) and non-loanees (56 per cent) insurance users. Cultivation is the major source of income for both users and non-users, followed by non- agricultural wages, salary and small trade (Table 4).

Agrarian Economy: Paddy is the staple cereal crop grown in the study area. Also some farmers cultivate other crops like cotton, maize, arhar, groundnut, ginger, turmeric and sunflower. But most of the farmers depend upon paddy cultivation. Paddy is cultivated during the kharif season. The farmers in the study area mainly practise rainfed farming as there is neither surface water nor groundwater available.

During kharif 2011, the yield rate of paddy for loanee and non-loanee insurance users and non-users was 9.72 quintals, 4.42 quintals and 5.01 quintals per hectare, respectively. The loanee insurance users thus have a high yield rate.The net income per hectare of kharif paddy is negative for both users and non-users, indicating loss in paddy cultivation across all farmer categories. The amount of loss is more in case of non-loanee insurance users ( $₹ 8658$ per hectare) because of which they have adopted crop insurance voluntarily (Table 4).

Almost all the households had a below normal yield. According to the farmers, normally they obtained an average yield of 27 to 29 quintals of paddy per hectare in the kharif season. But in the survey year which was a drought year, the loanee farmers had a paddy yield of ten quintals per hectare while it was only four quintals for non-loanees and five quintals for non-users. Thus, in rainfed agriculture, farming is not profitable and subject to a lot of risks. 
Table 4: Socio-economic Profile of Insurance Users and Non-users

\begin{tabular}{|lccc|}
\hline Characteristics & $\begin{array}{c}\text { NAIS Users } \\
\text { Loanee }\end{array}$ & $\begin{array}{c}\text { NAIS } \\
\text { Non-loanee }\end{array}$ & Non-users \\
\hline Total Households & 100 & 50 & 50 \\
Caste in \% & & & \\
General & 5.0 & 10.0 & 0.0 \\
Socially and economically backward classes & 81.0 & 76.0 & 56.0 \\
Scheduled castes & 5.0 & 4.0 & 20.0 \\
Scheduled tribes & 9.0 & 10.0 & 24.0 \\
Family Size (Member per Household) & 6 & 4 & 4 \\
Education in \% & & & \\
Below primary & 13.0 & 8.0 & 18.0 \\
Primary and above & 87.0 & 92.0 & 82.0 \\
Farmer Class in \% & & & \\
MF/SF & 36.0 & 56.0 & 76.0 \\
Others & 64.0 & 44.0 & 24.0 \\
Yield rate (Qt//Ha) & 9.72 & 4.42 & 5.01 \\
Income (Rupees/Household) & & & \\
\% of Income from cultivation & 56.0 & 70.0 & 68.0 \\
\% of Income from non-agricultural wages & 15.0 & 10.0 & 14.0 \\
\% of Income from other sources & 29.0 & 20.0 & 18.0 \\
Farm Income & & & \\
Gross income/ hectare (in ₹) & 9724 & 4420 & 5007 \\
Total cost of cultivation/ hectare (in ₹) & 14717 & 17806 & 18318 \\
Imputed value of family labour/ hectare (in ₹) & 2770 & 4728 & 5834 \\
Paid-out cost of cultivation/ hectare (in ₹) & 11947 & 13078 & 12483 \\
Net income/ hectare (in ₹) & -2222 & -8658 & -7476 \\
\hline
\end{tabular}

Determinants of Participation: The survey tried to find out the factors which have a positive influence on the adoption behaviour of the farmers. The loanees are compulsorily covered under NAIS, therefore the option of buying insurance does not arise for them. But the nonloanees have adopted crop insurance voluntarily even if they have not availed any crop loans from institutional sources during the crop season whereas the non-users have not gone for insurance. Therefore, to identify the factors that influence the adoption of crop insurance, the ttest was applied to find out level of significance between mean difference of various socioeconomic variables of the non-loanee users and non-users of NAIS (Table 5). 
Table 5: Socio-economic Characteristics of Non-loanee NAIS Users and NAIS Non-Users

\begin{tabular}{|lccccccc|}
\hline Parameter & \multicolumn{2}{c}{$\begin{array}{c}\text { Non-loanee } \\
\text { Non-Users }\end{array}$} & \multicolumn{2}{c}{ NAIS Users } & \multicolumn{3}{c|}{ NAIS } \\
\hline & Mean & S.D. & Mean & S.D. & \\
Farm size (Acres) & 6.29 & 5.36 & 4.75 & 5.41 & 1.55 & 1.59 & $*$ \\
Age (Numbers) & 49.76 & 12.95 & 46.72 & 11.01 & 3.04 & 1.23 & NS \\
Family size (Numbers) & 4.20 & 1.91 & 4.28 & 1.67 & -0.08 & -0.21 & NS \\
Education (Years) & 8.16 & 4.44 & 7.20 & 4.42 & 0.96 & 1.09 & NS \\
Household income (₹) & 69356 & 50795 & 55200 & 31710 & 14156 & 1.83 & $*$ \\
Income from & & & & & & & \\
Cultivation (₹) & 34260 & 22215 & 28220 & 28014 & 6040 & 1.51 & $*$ \\
Others (₹) & 35096 & 44135 & 26980 & 21429 & 8116 & 1.15 & NS \\
\hline
\end{tabular}

Note: ** Significant at 5 per cent level * Significant at 10 per cent level NS Not Significant

The survey tried to find out the factors which have a positive influence on the adoption behaviour of the farmers. A comparison between them through the t-test shows that the non-loanees who have opted for insurance have a significantly higher income from cultivation.Thus, farmers who are more dependent upon cultivation are more exposed to risk and hence are insuring their crops.

Also, it is found that farm size and household income significantly and positively influence the adoption of insurance. The household income of non-loanees was much higher than the household income of nonusers as shown in Table 5. Income from cultivation generally corresponds to farm size. As can be observed, both farm size and income from cultivation were significantly higher for non-loanees as compared to non- users. Thus, farmers depending more on cultivation are more exposed to risk and hence have voluntarily adopted crop insurance as a risk management tool. While, large farmers are adopting crop insurance, factors such as farm size and income from livestock also significantly and positively influenced the adoption of insurance.

Moreover, it can be observed from Table 5 that there is no significant difference between the age of non-loanees and nonusers. Average family size is also 4 among both non-loanee users and non-users. Most of the respondents in both categories have education up to middle level. This shows that there is no significant difference in level of education between non-loanees and nonusers. 
Risk Management Tools: Considering the overall importance and intensity of risk in agriculture, assessment and management of risks in agriculture is an important issue. As reported by the respondents, drought is the major risk factor in the study area. In the study villages, drought conditions are not created by just deficits in rainfall but variability in rainfall. Drought is a chronic phenomenon in the area and occurs almost every other year. Other important risk factors in the study area are variability in rainfall and pest attack.

The farmers adopt various strategies to manage risk in case of crop loss due to occurrence of natural calamities, pest attacks or plant diseases. Crop insurance is considered as one of the important tools to manage risk by loanee insurance users. But the non-loanee insurance users and non-users consider offfarm employment as more effective in managing risk. Diversification of farming is also resorted to as a risk management tool by both loanee and non-loanee insurance users.

Reasons for Adopting Crop Insurance: The survey shows various reasons as to why the users of crop insurance have insured their crops. The non-loanees were found to be more inclined to avoid risk because of which they had voluntarily opted for crop insurance. The loanee NAIS users considered financial security as the main reason for insuring their crop. Crop insurance is thus, recognised to be a basic instrument for maintaining stability in farm income. The farmers expect that crop insurance should cushion the shock of crop loss by assuring them protection against natural hazards beyond their control. But, even if there is a need for crop insurance in the risky environment of the study area, farmers are not coming forward in large numbers to insure their crops. Hence, the efficacy of the existing insurance scheme is assessed by eliciting the satisfaction and dissatisfaction level of insurance users. Also an attempt has been made to identify the causes of dissatisfaction.

Satisfaction with Crop Insurance: The farmers were asked to rate their level of satisfaction with the insurance schemes, the results of which are given in Table 6 . The results show only 7 per cent of the total loanee NAIS users and 24 per cent of the non-loanee NAIS users expressed satisfaction with the scheme. It is observed that most of the insured farmers are thus, dissatisfied with the scheme or are neutral having no strong opinion on the scheme.

Table 6: Satisfaction of Insurance Users with NAIS: Frequency of Responses of Insurance Users

Number of Households

\begin{tabular}{|lcc|}
\hline Level of Satisfaction & NAIS Loanee & NAIS Non-loanee \\
\hline Strongly dissatisfied & 23 & 1 \\
& $(23.0)$ & $(2.0)$ \\
Dissatisfied & 43 & 27 \\
& $(43.0)$ & $(54.0)$ \\
\hline
\end{tabular}

(Contd.........) 
Table 6 (Contd.....)

\begin{tabular}{|lcc|}
\hline Neither satisfied nor dissatisfied & 27 & 10 \\
& $(27.0)$ & $(20.0)$ \\
Satisfied & 7 & 12 \\
& $(7.0)$ & $(24.0)$ \\
Strongly satisfied & 0 & 0 \\
& $(0.0)$ & $(0.0)$ \\
Total & 100 & 50 \\
& $(100.0)$ & $(100.0)$ \\
\hline
\end{tabular}

Note: Figures in parentheses indicate percentages of total.

In order to find out the reasons for their dissatisfaction, the insurance users were asked to rank the three most important reasons as 1st, 2nd and 3rd.The percentage weighted score is calculated by assigning the value of 3 , 2 and 1 to first important, second important and third important rank, respectively. Table 7 gives the data on the frequency of responses and the percentage weighted score on various causes of dissatisfaction.

The loanees were not satisfied with crop insurance as the loss assessment unit was very large (37.0 per cent). The nonloanees, on the contrary, gave the highest score of 41.5 per cent to delay in compensation payment. The next important reason for dissatisfaction for both the loanees and non-loanees was that individual and independent risk was not covered. Moreover, the insurance users were not satisfied with the lower amount of compensation received (Table 7).

Thus, the important reasons for dissatisfaction with the scheme as reported by insurance users were loss assessment unit of area was very large and individual and independent risk was not covered. The users also complained about undue delay in payment of compensation.

During personal interaction with insurance users, it was observed that many loanee farmers covered under NAIS indicated ignorance about the coverage of their crops under crop insurance. The farmers did not know whether they were covered under crop insurance scheme, as the premium rate was automatically deducted from the sanctioned loan amount. Further, since the compensation was deposited with the borrowers' loan accounts and adjusted as repayment of loan, the farmers had no knowledge about the amount of compensation paid to them and when it was deposited. Thus, the insurance users could not appreciate the benefits of insurance. Moreover, there was undue delay (more than six months) in payment of compensation as the assessment of yield on the basis of crop cutting experiments was a time-consuming process. On the whole, NAIS failed to stabilise the insurance users' income and provide them economic support during adverse circumstances. 
Table 7: Reasons for Dissatisfaction with Crop Insurance Scheme: Frequency of Responses of Insurance Users

Number of Households

\begin{tabular}{|c|c|c|c|c|c|c|c|c|}
\hline Reasons & & NAIS & oanee & & & NAIS $\mathrm{Nc}$ & ר-Ioanee & \\
\hline & $\begin{array}{c}\text { 1st } \\
\text { Reason }\end{array}$ & $\begin{array}{l}\text { 2nd } \\
\text { Reason }\end{array}$ & $\begin{array}{c}\text { 3rd } \\
\text { Reason }\end{array}$ & $\begin{array}{l}\text { Weighted } \\
\text { Score in \% }\end{array}$ & $\begin{array}{c}\text { 1st } \\
\text { Reason }\end{array}$ & $\begin{array}{c}\text { 2nd } \\
\text { Reason }\end{array}$ & $\begin{array}{c}\text { 3rd } \\
\text { Reason }\end{array}$ & $\begin{array}{l}\text { Weighted } \\
\text { Score in \% }\end{array}$ \\
\hline 1. High premium & 0 & 0 & 0 & 0.0 & 0 & 0 & 3 & 1.3 \\
\hline $\begin{array}{l}\text { 2. Delay in } \\
\text { compensation } \\
\text { payment }\end{array}$ & 18 & 16 & 45 & 23.4 & 24 & 11 & 1 & 41.5 \\
\hline $\begin{array}{l}\text { 3. Loss assessment } \\
\text { unit is very } \\
\text { large }\end{array}$ & 45 & 31 & 14 & 37.0 & 0 & 0 & 1 & 0.4 \\
\hline $\begin{array}{l}\text { 4. Individual, } \\
\text { independent } \\
\text { risk is not } \\
\text { covered } \\
\text { 5. Proper facilities } \\
\text { are not available }\end{array}$ & 27 & 40 & 22 & 32.6 & 3 & 20 & 13 & 27.1 \\
\hline
\end{tabular}

Note: The total number of satisfied loanee NAIS users is 7 and satisfied non-loanee users is 12 .

Reasons for Non-adoption of Crop Insurance: The farmers in the study area who were not currently covered by crop insurance were interviewed to explore the reasons for nonadoption of NAIS. Table 8 gives the data on the frequency of responses and the percentage weighted score on various causes of nonadoption by the non-users.

Most of the non-users were unaware about crop insurance (62 per cent). Among those who were aware about the scheme, the most important reason of dissatisfaction was that there was lack of co-operation from banks and cooperatives (10 per cent) which were the main providers of insurance. Also, they found the whole concept of insurance too complicated to understand (9 per cent) and some were not aware of the facilities available (5.3 per cent). Thus, lack of awareness about the crop insurance scheme was the single most important reason for non-adoption of crop insurance.

Table 8: Reasons for Not Availing of Crop Insurance Scheme: Frequency of Responses of Insurance Non-users Number of Households

\begin{tabular}{|c|c|c|c|c|}
\hline \multirow[t]{2}{*}{ Reasons } & \multicolumn{3}{|c|}{ Non-user Rank } & \multirow[b]{2}{*}{$\begin{array}{l}\text { Weighted } \\
\text { Score in \% }\end{array}$} \\
\hline & $1^{\text {stReason }}$ & $2^{\text {nd }}$ Reason & $3^{\text {rd Reason }}$ & \\
\hline Not aware of crop insurance & 31 & 31 & 31 & 62.0 \\
\hline Too complicated to understand and use & 3 & 7 & 4 & 9.0 \\
\hline
\end{tabular}


Table 8 (Contd.....)

\begin{tabular}{lcccc}
\hline Govt. will provide disaster relief/aid & - & 1 & - & 0.7 \\
Lack of premium paying capacity & - & - & - & 0.0 \\
Not aware of the facilities available & 1 & 5 & 3 & 5.3 \\
Not satisfied with crops covered & - & 1 & - & 0.7 \\
Not satisfied with area approach & - & 1 & - & 0.7 \\
Inadequate publicity of the scheme & - & - & 2 & 0.7 \\
Complex documentation & 6 & 2 & 2 & 8.0 \\
Lack of service/cooperation from the bank & 8 & 2 & 2 & 10.0 \\
No faith in scheme & - & - & 2 & 0.7 \\
Delay in claim payment & - & - & - & 0.0 \\
Not satisfied with indemnity level & - & - & - & 0.0 \\
Difficulties in opening bank accounts & 1 & - & - & 1.0 \\
Others (specify) & - & - & 4 & 1.3 \\
Total & 50 & 50 & 50 & 100.0
\end{tabular}

Improving Scheme Performance: The respondents were interviewed to suggest measures to improve the operational efficiency of the scheme.Table 9 throws light on various suggestions given by the respondents. The Table shows that majority of the loanees (34.2 per cent) suggested that individual assessment of crop loss would improve the operational efficiency of the scheme. Others were of the view that the scheme should be made voluntary and gram panchayat should be considered as unit of loss assessment. The non-loanees and non-users suggested that settlement of claims should be quick. While the loanees wanted the scheme to be voluntary, the non-loanees and non-users wanted the insurance service should be provided at the door-step of farmers. 


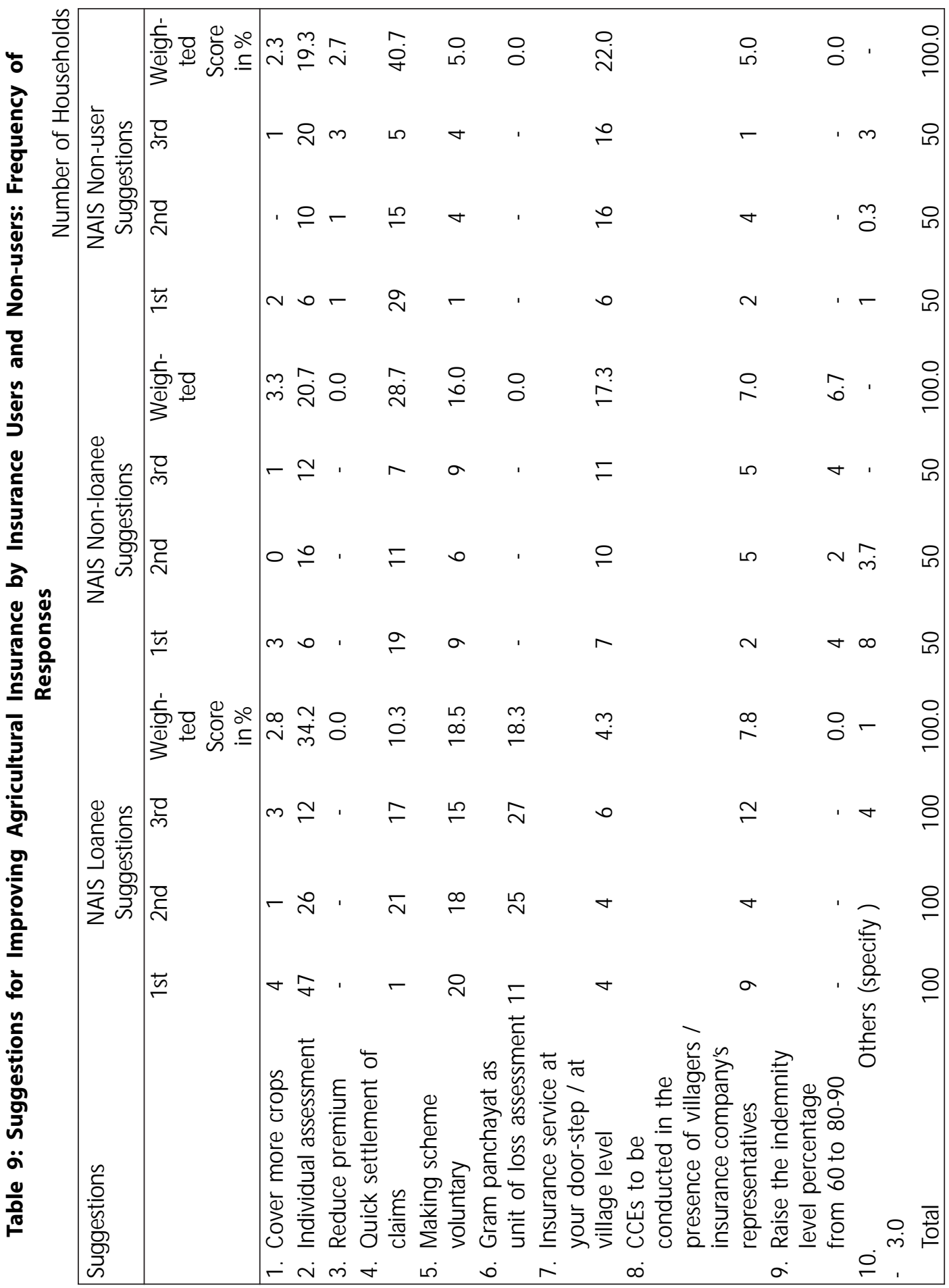

Journal of Rural Development, Vol. 36, No. 3, July-September : 2017 
The farmers were asked to express their views on the reasonableness of the premium rate paid for insuring the crops under NAIS. Most of the farmers were of the view that the premium was reasonable and affordable (Table 10). As high as 89 per cent of loanee NAIS users and 98 per cent of nonloanee NAIS users considered the premium they paid for availing crop insurance to be reasonable. This suggests that no further subsidy is required to incentivise farmer participation in the insurance market.

Table 10: Opinion on Premium Paid by Insurance Users: Frequency of Responses of Insurance users Percentage of Households

\begin{tabular}{|lcc|}
\hline $\begin{array}{l}\text { Level of } \\
\text { Premium }\end{array}$ & $\begin{array}{c}\text { NAIS } \\
\text { Loanee }\end{array}$ & $\begin{array}{c}\text { NAIS Non- } \\
\text { loanee }\end{array}$ \\
\hline Very low & 0.0 & 0.0 \\
Low & 10.0 & 2.0 \\
Reasonable & 89.0 & 98.0 \\
High & 1.0 & 0.0 \\
Very high & 0.0 & 0.0 \\
Total & 100.0 & 100.0 \\
\hline
\end{tabular}

It is important to analyse how much amount the farmers are willing to pay as insurance premium for their crops. Farmers were personally interviewed about the amount they were willing to pay as premium for insuring their crops. A majority of loanees (52.1 per cent) were willing to pay a premium of 2-3 per cent of the sum insured while most of the non-loanees (44.7 per cent) were willing to pay a premium of 4-5 per cent of the sum insured (Table 11). While as high as 52.1 per cent of the loanees were willing to pay a premium of $₹ 200$ to $₹ 300$ per acre, 44.7 per cent of the non-loanees were willing to pay a premium of ₹ 400 to 500 per acre. This shows that the non-loanees are willing to pay a higher rate of premium than the loanees to insure their crop against production risk, as they are more risk averse.

Table 11: Acceptable Rate of Premium: Frequency of Responses of Insurance Users

Percentage of Households

\begin{tabular}{|c|c|c|}
\hline & NAIS Loanee & $\begin{array}{l}\text { NAIS Non- } \\
\text { loanee }\end{array}$ \\
\hline \multicolumn{3}{|c|}{$\%$ of Sum Assured } \\
\hline Up to $2 \%$ & 41.5 & 10.5 \\
\hline $2-3 \%$ & 52.1 & 28.9 \\
\hline $3-4 \%$ & 4.3 & 15.8 \\
\hline $4-5 \%$ & 2.1 & 44.7 \\
\hline \multicolumn{3}{|l|}{ ₹ Per Acre } \\
\hline Up to 200 & 41.5 & 10.5 \\
\hline $200-300$ & 52.1 & 28.9 \\
\hline $300-400$ & 4.3 & 15.8 \\
\hline $400-500$ & 2.1 & 44.7 \\
\hline
\end{tabular}

Preference for Media: The low coverage of insurance has been attributed to lack of adequate awareness generation activities by insurance agencies. Thus, we have tried to find out the various mediums which are more effective in generating awareness among farmers about insurance.

As revealed in Table 12, a majority of the respondents preferred media like farmers' meeting (kisan sabha) and village fair to get proper information. Popular mass media like television, film shows and newspaper were also preferred by the farmers. 


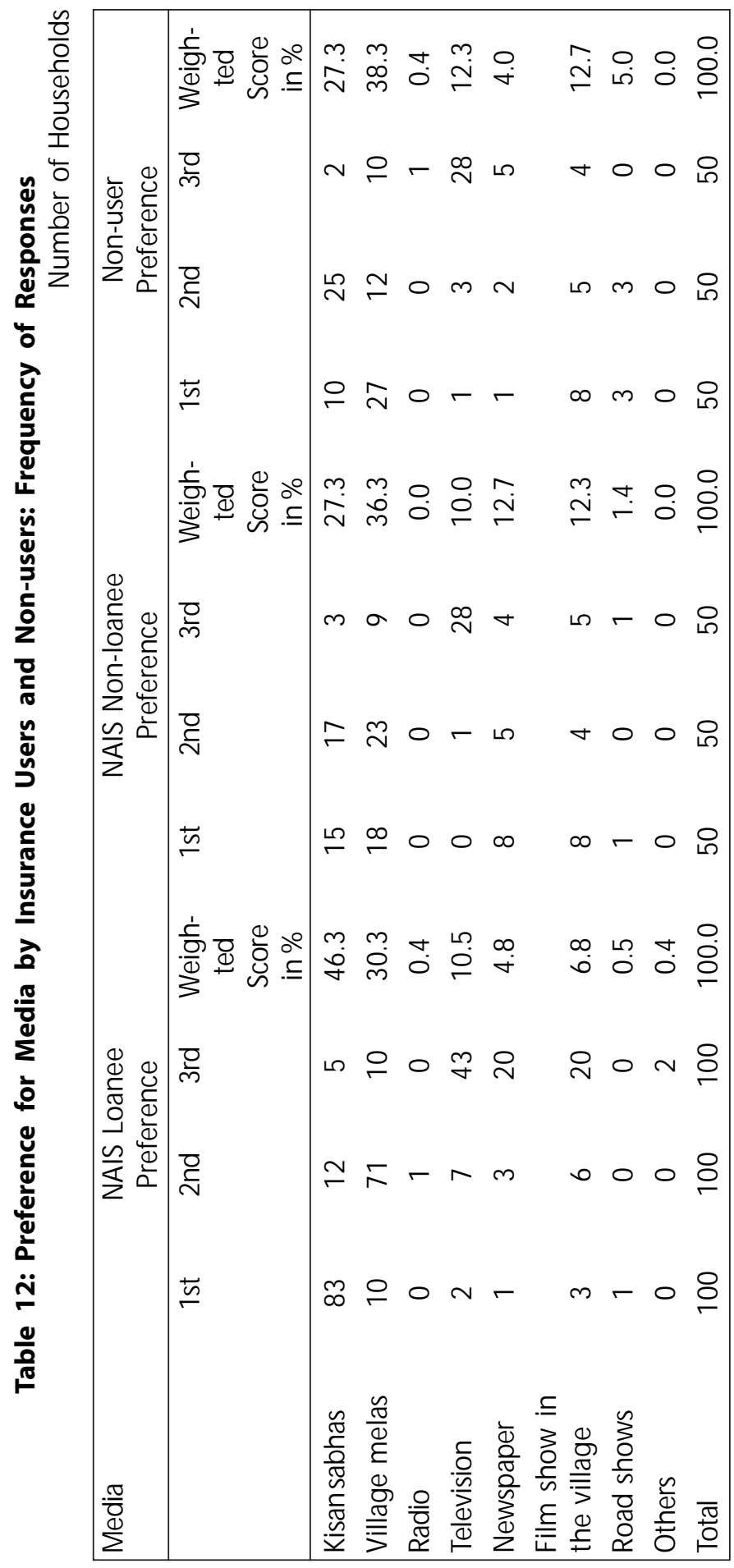

Journal of Rural Development, Vol. 36, No. 3, July-September : 2017 
Preference for Service Provider: To increase the coverage of the scheme, policy makers would need to take necessary steps to provide insurance services in a conducive atmosphere by friendly agents. In this context, the responses of the surveyed households were elicited regarding the different agents who, according to them, would be more helpful in providing them adequate insurance services.
According to majority of the users and non-users, rural agents at the door-step and at the village level would be better service providers. While the loanees considered that cooperative banks also would provide better insurance services, the non-loanees and the non-users expressed preference for the SelfHelp Groups (SHGs) as a better provider of insurance service (Table 13). Thus, it is observed that rural agents who can come to individual household at the village level are preferred to other service providers of insurance. 


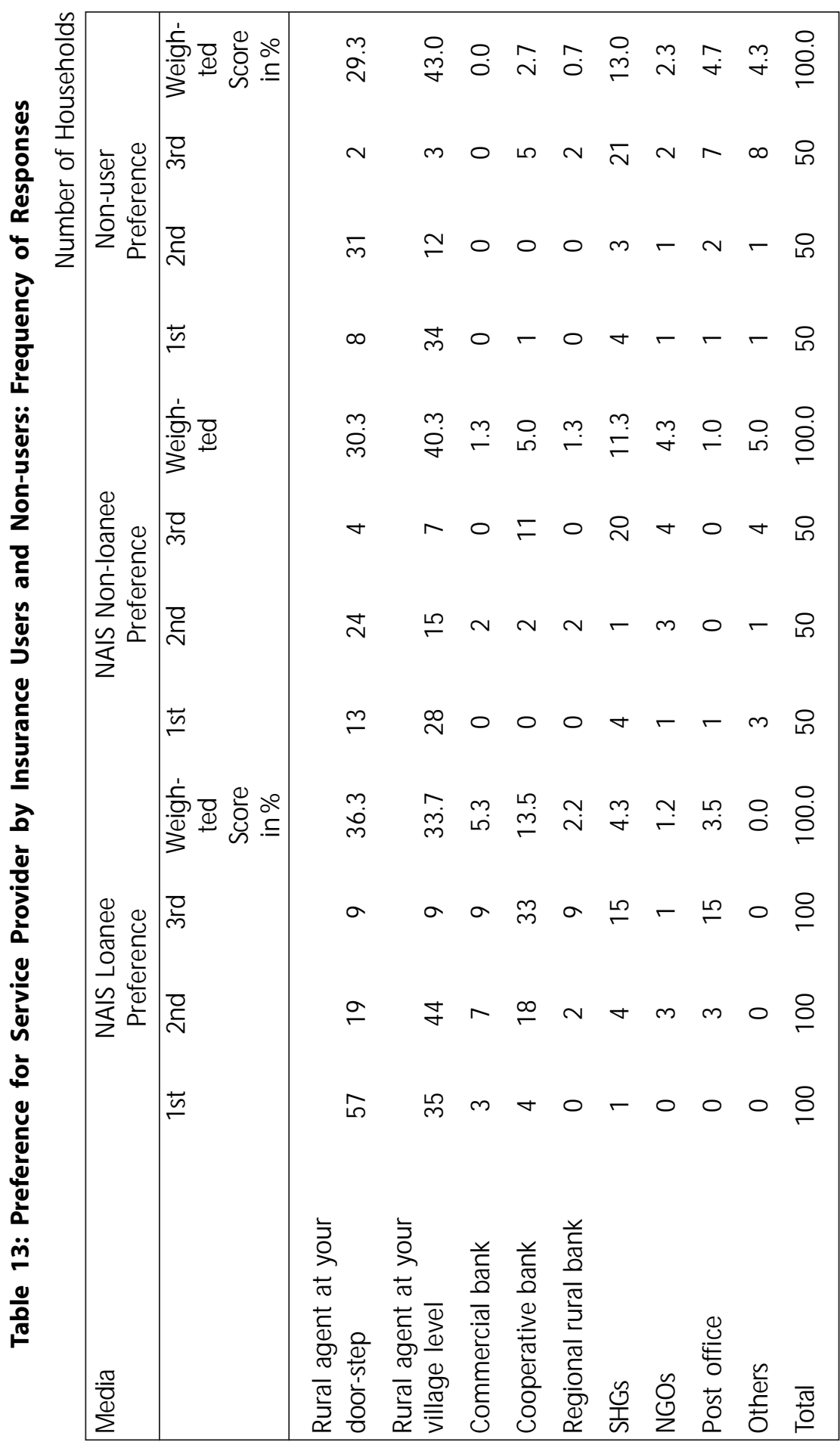

Journal of Rural Development, Vol. 36, No. 3, July-September : 2017 
Preference for Insurance Product: During the field survey it was found that the surveyed households did not seem satisfied with NAIS which is a crop yield insurance scheme. The insurance users were then asked to express their preference for different types of insurance products: crop yield insurance, rainfall insurance and revenue insurance. While, rainfall insurance provides coverage for crop yield losses due to rainfall, revenue insurance covers both yield and price risk. Table 14 shows the preference of both insurance users and non-users for different types of insurance products.

Both the users and non-users of NAIS have given a greater preference to rainfall insurance in comparison to crop yield insurance. They have expressed their preference for revenue insurance also.

Table 14: Preference for Insurance Product by Insurance Users and Non-users: Frequency of Response

Number of Households

\begin{tabular}{|c|c|c|c|c|c|c|c|c|c|c|c|c|}
\hline \multirow[t]{2}{*}{$\begin{array}{l}\text { Insurance } \\
\text { Scheme }\end{array}$} & \multicolumn{4}{|c|}{$\begin{array}{l}\text { NAIS Loanee } \\
\text { Preference }\end{array}$} & \multicolumn{3}{|c|}{$\begin{array}{c}\text { NAIS } \\
\text { Non-loanee } \\
\text { Preference }\end{array}$} & \multicolumn{5}{|c|}{$\begin{array}{l}\text { Non-user } \\
\text { Preference }\end{array}$} \\
\hline & 1st & 2nd & $3 \mathrm{rd}$ & $\begin{array}{l}\text { Weigh- } \\
\text { ted } \\
\text { Score } \\
\text { in \% }\end{array}$ & 1st & 2nd & 3rd & $\begin{array}{l}\text { Weigh- } \\
\text { ted } \\
\text { Score } \\
\text { in \% }\end{array}$ & 1st & 2nd & & $\begin{array}{c}\text { Weigh- } \\
\text { ted } \\
\text { Score } \\
\text { in \% }\end{array}$ \\
\hline $\begin{array}{l}\text { Crop } \\
\text { Insurance }\end{array}$ & 27 & 61 & 12 & 35.8 & 14 & 24 & 12 & 34.0 & 7 & 20 & 23 & 28.0 \\
\hline $\begin{array}{l}\text { Rainfall } \\
\text { Insurance }\end{array}$ & 71 & 26 & 3 & 44.7 & 36 & 12 & 2 & 44.7 & 34 & 12 & 4 & 43.3 \\
\hline $\begin{array}{l}\text { Revenue } \\
\text { Insurance }\end{array}$ & 2 & 13 & 85 & 19.5 & 0 & 14 & 36 & 21.3 & 9 & 18 & 23 & 28.7 \\
\hline
\end{tabular}

\section{Conclusions and Policy Implications}

An assessment of the performance of NAIS in Odisha in the foregoing paragraphs reveals that the scheme has not received wide acceptance from farmers.

The scheme is operational mainly because the farmers availing of loan from institutional sources like cooperatives, regional rural banks and commercial banks are compulsorily covered under the scheme. As shown in the study analysis, during kharif 2011 , the average of the percentage of nonloanee farmers covered under NAIS across the State was only 12.3. Thus, voluntary participation in NAIS has been very low in the State which is a matter of great concern. The scheme has a greater coverage in the agriculturally more advanced coastal region of Odisha due to better access of farmers to institutional sources of finance. However, in the case of drought-prone Kalahandi district, 
the adoption rate of NAIS by non-loanee farmers is quite high in comparison to other developed districts of Odisha. Thus, in risky areas the farmers voluntarily come forward to insure their crops.

Drought is the major risk factor in the study region of Kalahandi district. Crop insurance is recognised to be a basic instrument for maintaining stability in farm income, through promoting technology, encouraging investment and increasing credit flow to the agriculture sector. An analysis of the determinants of participation in crop insurance schemes reveals that farmers who are more dependent upon cultivation are more exposed to risk and hence are insuring their crops. Also, other factors such as farm size and household income significantly and positively influence the adoption of insurance.

Despite being one of the important tools of risk management in drought-prone areas,NAIS has not gained wide acceptance. Also, most of the insurance users were either dissatisfied with the scheme or remained neutral expressing no strong opinions on the scheme. The important reasons for dissatisfaction with the scheme as reported by insurance users are: loss assessment unit of area is very large and individual and independent risk is not covered. The users also complained about undue delay in payment of compensation. The non-users had not adopted insurance due to lack of awareness.
Therefore, to increase the coverage of the schemes, there is need to create awareness about the benefits of such schemes among farmers. Steps should be taken to explain the operational mechanisms of different insurance schemes to farmers in simple terms in their local language. Moreover, education, training and capacity building should be imparted among local insurance service providers and bank officials as well as the consumers of insurance products. Rural agents who can come to individual household and at the village level can act as better service providers of insurance.

As NAIS is an area-based agricultural insurance scheme, it does not cover independent, idiosyncratic and individual risk. To make this possible, the public sector could undertake to address catastrophic risk and provide multi-peril insurance where the subsidy requirement is high while the private sector could be brought in to provide insurance products for less severe events and for individual, independent, idiosyncratic and localised risk at actuarial premium.This means policy makers should take steps to create an atmosphere conducive for the promotion of private sector participation in agricultural insurance. At the same time, the policy designers must encourage micro-insurance, i.e., insurance for the poor, through the participation of banks, non-governmental organisations and microfinance institutions. 


\section{References}

1. Agricultural Insurance Company of India Limited (2007), "Crop Insurance in India."

2. Ahmed, A.U., M.Alam and A.A. Rahman (1998), "Adaptation to Climate Change in Bangladesh: Future Outlook," In 'Vulnerability and Adaptation to Climate Change for Bangladesh,' S. Huq, Z. Karim, M. Asaduzzaman, and F. Mahtab (Eds.), Kluwer Academic Publishers, Dordrecht, pp. 125-143.

3. Binswanger, H.P. and M.R. Rosenzweig (1986), "Behavioural and Material Determinants of Production Relations in Agriculture,"Journal of Development Studies, Vol.22, pp.503-539.

4. Carter, M.R. and C.B. Barrett (2006), "The Economics of Poverty Traps and Persistent Poverty: An Asset Based Approach,"Journal of Development Studies, Vol.42, pp.178-199.

5. Miranda, M.J., J.W. Glauber (1997), "Systemic Risk, Reinsurance, and the Failure of Crop Insurance Markets,"American Journal of Agricultural Economics, Vol.79, No. 1, pp. 206-215.

6. Swain, Mamata (2008), "Agricultural Risk and Crop Insurance in Orissa in a Globalised Economy," Man and Development, Vol.30, No. 3, pp.107-128.

7. $\quad$--- (2014), “Crop Insurance for Adaptation to Climate Change in India,” Working Paper No. 61, Asia Research Centre, London School of Economics and Political Science, London.

8. Swain, Mamata and Patnaik, Sasmita (2016), "Performance Assessment of Crop Insurance Schemes in Odisha in Eastern India," Working Paper No. 104- 16, South Asian Network for Development and Environmental Economics (SANDEE), Kathmandu, ISSN 1893-1891. 